\title{
The Long-Run Impact of Factors Driving Africa's Recent Growth Performance: An Empirical Investigation
}

\author{
Hopestone Kayiska Chavula \\ Macroeconomic Policy Division Economic Commission for Africa, Addis Ababa, Ethiopia \\ Email:Chavulah@yahoo.com
}

Received 20 April 2016; accepted 25 July 2016; published 28 July 2016

Copyright @ 2016 by author and Scientific Research Publishing Inc.

This work is licensed under the Creative Commons Attribution International License (CC BY).

http://creativecommons.org/licenses/by/4.0/

(c) (i) Open Access

\section{Abstract}

The paper empirically examined the long-run impact of factors believed to have been driving Africa's recent growth performance, using the recent analytical methodology, the pooled mean group (PMG) approach, over the period 1980-2013. The results support the narrative that Africa's recent growth has mainly been driven by improved macroeconomic management associated with improved fiscal consolidation and monetary policy measures being undertaken by most African countries, the demographic influences as a result of increasing working-age population, trade especially as a result of relatively high commodity prices experienced over the period. However, the results show also that foreign debt, inflation rate and FDI (as a greater percentage is directed towards extractive industries) continue to weigh negatively on growth in the long-run.

\section{Keywords}

\section{Africa, Recent Growth, Pooled Mean Group Estimation (PMG), Macroeconomic Management}

\section{Introduction}

African countries have experienced significant economic growth performance over the past decade, with a number of countries experiencing an average economic growth of over 7\%, and GDP per capita averaging US\$946 over the period 1980-99 while increasing to US\$1614 over the period 2000-13 (Table 1). The region has experienced increasing investment, and domestic credit to the private sector, total trade and consumption expenditure with significant declines in total debt as a percentage of GDP and inflation rate over the years. It has also experienced increases in overall trade, increasing working-age population (aged 15 - 64), and terms of trade (Figure 1). FDI net inflows as a percentage of GDP, working-age population, credit to the private sector 
Table 1. Economic fundamentals over the two periods, 1980-1999 and 2000-2013.

\begin{tabular}{ccccc}
\hline & \multicolumn{2}{c}{$1980-1999$} & \multicolumn{2}{c}{$2000-2013$} \\
\hline No. of observations & \multicolumn{2}{c}{311} & Mean & Std. Err. \\
\hline Variable & Mean & Std. Err. & 1614.33 & 100.7506 \\
\hline GDP per capita & 945.7575 & $(58.75119)$ & 22.8486 & 0.4185061 \\
Gross capital formation & 21.8569 & 0.6236674 & 4.350426 & 0.2980835 \\
FDI net inflows & 1.660072 & 0.2556347 & 7.602776 & 0.2000825 \\
Public invest. (\%GDP) & 8.879247 & 0.3007102 & 14.22882 & 0.3378688 \\
Private invest. (\%GDP) & 14.07851 & 0.5129147 & 103.0571 & 1.03696 \\
Primary education & 87.10338 & 1.571724 & 55.95213 & 0.3010879 \\
Population 15 - 64 & 53.28569 & 0.2573083 & 2.290563 & 0.0458587 \\
Population growth & 2.508483 & 0.0652767 & -2.160211 & 0.2567121 \\
Fiscal balance & -2.875114 & 0.3204948 & 53.92505 & 1.992051 \\
External debt (\% of GDP) & 79.43013 & 3.333907 & 25.92097 & 1.477892 \\
Credit to private sector & 20.00677 & 1.102684 & 109.7408 & 0.8976776 \\
Domestic demand & 109.881 & 0.317373 & 9.810229 & 0.5289201 \\
Real interest rate & 7.120834 & 0.7857104 & 96.00119 & 1.58689 \\
REER (1997 = 100) & 136.1643 & 14.39596 & 8.663156 & 1.180876 \\
Inflation & 14.38074 & 1.279202 & 73.46059 & 1.614753 \\
Trade openness & 66.69018 & 1.977268 & 103.9135 & 4.857099 \\
Px/Pm & 103.2714 & 2.516365 & 243.7542 & 22.48241 \\
Px/Py & 227.589 & 729.5908 & & \\
\hline
\end{tabular}

Source: World Bank [8] and EIU [9].

and trade openness increased from an average of 1.7\%, 53.3\%, 20.0\% and 66.7\% over the period $1980-99$ to an average of $4.4 \%, 56 \%, 25.9 \%$, and $73.5 \%$ over the period $2000-13$ respectively. While average fiscal balance, external debt as a percentage of GDP, and inflation declined from $-2.9 \%, 79.4 \%$ and $14.4 \%$ respectively over the period 1980-99, to an average of $-2.2 \%, 53.9 \%$ and $8.7 \%$ over the period $2000-13$ respectively (Table 1 ).

Soaring prices for oil, minerals and other commodities are believed to have had a significant impact in boosting Africa's trade and hence GDP over the past decade, however, they contribute only about a third of the continents recent growth. The rest results from internal structural changes which have spurred the broader domestic economy [1]-[3]. Indeed, countries with and without significant resource exports such as Ethiopia, Mauritius and Rwanda have had also similar GDP growth rates over the period. These resource-poor countries which are mainly oil-importing, also continue to grow mainly driven by strong expansion in non-mining sectors such as services and agriculture [4].

Despite experiencing some headwinds from political instability, terrorism threats, natural disasters, climate change, global economic slowdown or poor government policies in some countries, Africa's medium- to longterm, internal and external trends indicate that Africa's economic performance has been strong [5]. Mainly underpinned by increasing domestic demand, improving macroeconomic conditions, through microeconomic reforms to create a better business environment, increasing public investment (especially in infrastructure, a buoyant services sector, increasing trade and investment ties with emerging economies) as well as government action to end armed conflicts on the continent [6]. Africa's growth also increasingly reflects the social and demographic changes taking place in its economies, through increased urbanization, labor force and a rising middle-class, boosting Africa's domestic demand and productivity (as workers move from agriculture sector) and investments [2]. The rising share of Africa's working age population is increasing its productive potential at a time when most of the advanced economies face an aging population [7]. These structural changes on the continent have led to an increase in productivity by helping companies to achieve greater economies of scale, increased investment and become more competitive.

The emergence of new development partners, especially the South-South cooperation (SSC), has also opened up different choices of development tools and forms of institutional relationships, giving African countries more diverse options regarding the type of partnerships they want to pursue. Indeed, Africa's trade with the BRICS has grown faster than its trade with any other region, with their share of FDI inward stock and FDI inflows reaching $14 \%$ and $25 \%$ respectively in 2010 [10].

Although Africa's trade with and FDI from traditional partners remains critical, the largest increase in FDI to 


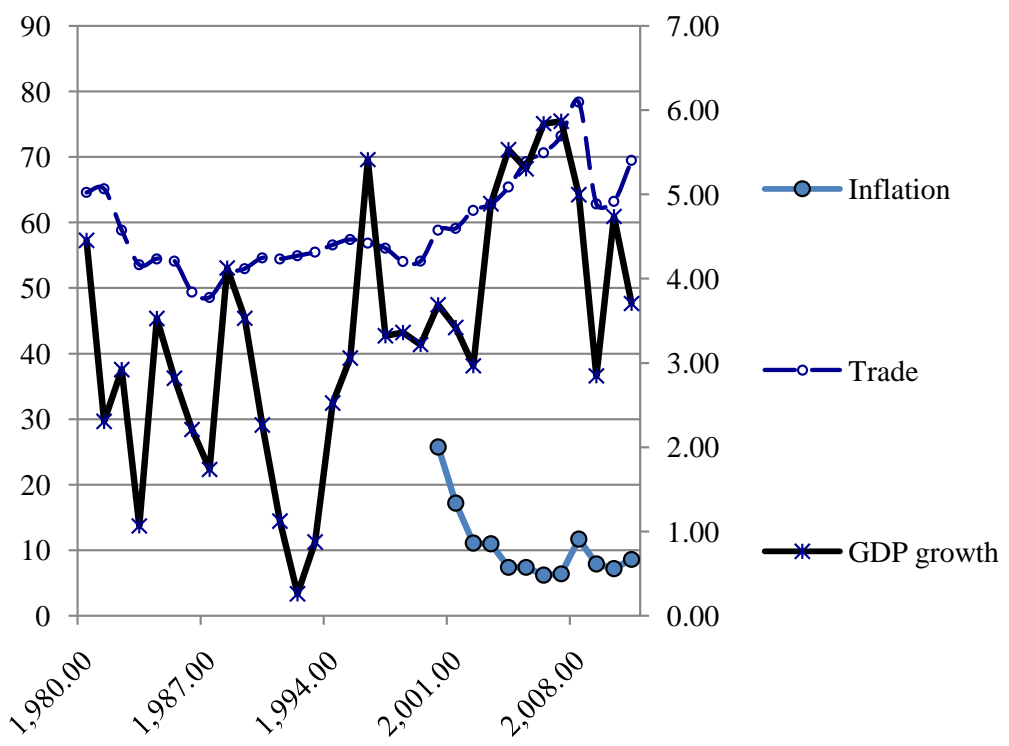

(a)

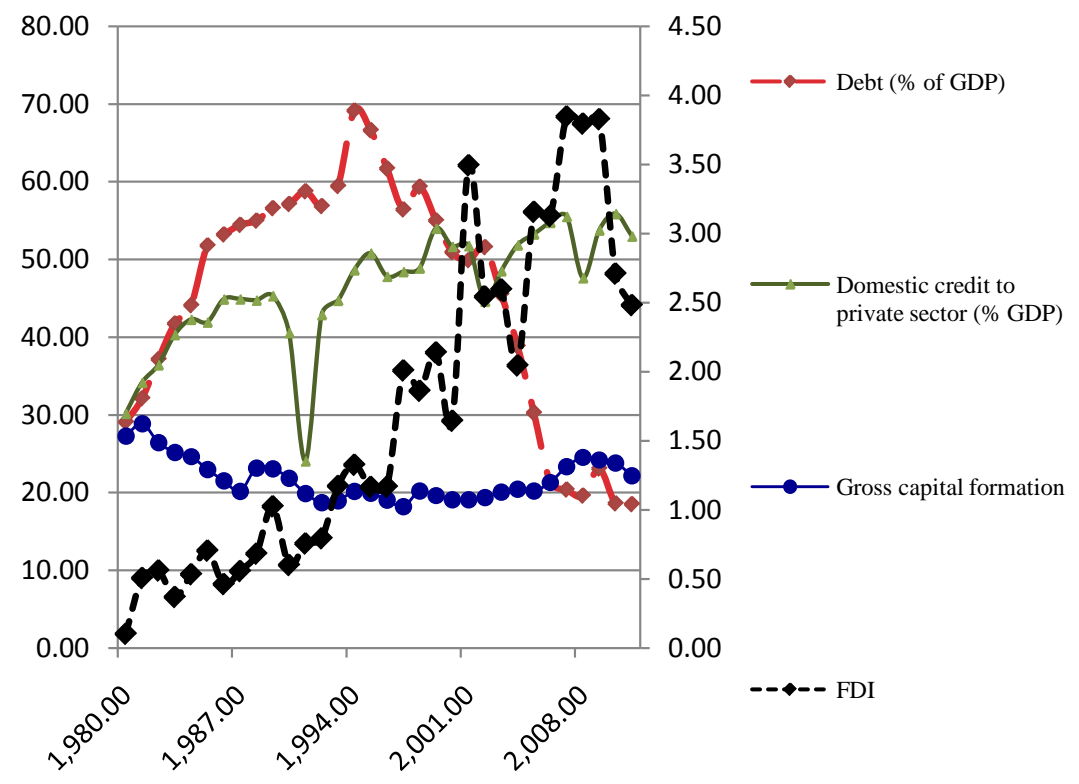

(b)

Figure 1. Macroeconomic performance of selected variables in Africa, 1980-2011. (a) Inflation, GDP growth and trade formation and FDI. Note: GDP is on the right axis; (b) Debt, domestic credit, gross capital. Note: FDI is on the left axis. Source: World Development Indicators (WDI) Database, 2015 [8] and EIU, 2015 [9].

Africa has come from the BRICS. Recent data suggest that FDI flows to Africa from India, China and Brazil have risen from $18 \%$ over the period $1995-1999$ to $21 \%$ over the period $2000-2008$. This surge in private capital flows to Africa reflects increased investors' appetite for new profit opportunities, rising consumer class, democratic dividend, as well as the success of macroeconomic and structural reforms in many African countries [1] [11].

While Africa's recent economic performance is widely recognized, its sources of growth and long-term sustainability power are less understood, and have not been empirically investigated. There have been no studies (to the author's knowledge) that have tried to empirically examine to what extent the factors believed to be behind Africa's recent growth performance have had long-term growth performance effects. The main aim of this paper 
is therefore to empirically examine to what extent the factors that are believed to be the sources of Africa's growth have underpinned Africa's recent robust economic performance in the long-run. This is done by using the policy variables that are deemed to be closely linked or associated with the factors driving growth or capture the effects of the different factors. The paper therefore renders significant contribution to Africa's recent growth by identifying factors have been behind this growth hence rendering advice to policy makers in terms of target areas that need attention to maintain and enhance this growth, such as reduction in external debt and targeting FDI into potential growth sectors.

The remainder of this paper is organized as follows: The next section introduces the empirical methodology used to estimate the short- and long-term impact of the factors driving Africa's recent growth. Section 3 presents the estimation techniques and the associated results, while Section 4 concludes.

\section{Methodology and Empirical Framework}

In order to empirically examine the short-run and long-run effects of the factors that are identified as having been behind the continent's recent growth performance, the following single equation error correction model is estimated:

$$
Y_{t}=\beta_{0}+\beta_{1} X_{t}+\beta_{2}\left[Y_{t-1}-X_{t-1}\right]+\theta Z_{t}+\varepsilon_{t}
$$

where $Y_{t}, X_{t}$, and $\left[Y_{t-1}-X_{t-1}\right]$ are the changes in log of income per capita, factors identified to have been behind Africa's recent growth performance and the error correction term, respectively. The later term captures the deviation from the long-run equilibrium, while $Z_{t}$ captures some country specific factors that would have had a significant impact on growth and not captured by the variables in the model.

As shown above literature reveals that Africa's recent growth has been underpinned by improvements in the countries' macroeconomic management, increased domestic demand, increased investment and trade ties with traditional and new partners, urbanization and some demographic factors as well as increases in global commodity prices over the years. These factors will be captured in the model through the vector $X_{t}$, through policy variables such as domestic demand, inflation, external debt, domestic credit, gross investment, terms of trade capturing the changes in global prices and the real effective exchange rate (REER), among others. The vector $X_{t}$ also consists of a set of control variables that have been identified in the economic growth literature as important control variables in cross-country growth models [12]-[14]. These variables include investment, human capital and population growth [13]. $Z_{t}$ includes the dummy variable capturing the effects of factors that have led to the structural shifts that occurred in the 2000s but not captured by vector $X_{t} .{ }^{1}$ The dummy variable takes the value 1 for the period 2005-2013 and zero otherwise. This takes care of the effects of institutional and regulatory factors as well as the prevailing peace keeping efforts on the continent which have had a significant impact on the countries' development, but have not been captured by the variables incorporated in the model.

From Equation (1), the coefficient $\beta_{1}$ captures the short-term effects of the economic fundamentals and factors behind Africa's recent growth, while the coefficient $\beta_{2}$ on the error correction term, estimates the speed of return to the long-run equilibrium after a short-run deviation. Of course this will be done after all the variables involved are statistically attested to be integrated of order one or I(1). After which we would then justify as to whether the single equation error correction approach involving the identified policy and control variables would be valid.

Panel data and the static fixed effect estimates have been suggested in the literature to take care of the problem of biased estimates due to the presence of omitted variable bias in cross section data in estimating growth regressions. It has also been shown that cross-section data with large samples of countries with growth averaged over a long period of time leads to biased estimates [15]. However, the static fixed effects estimators or pooled OLS, cannot be applied to growth regressions because of the presence of the lagged dependent variable, whose coefficient is biased and will only be consistent for large time periods [16]. This led to the development of the dynamic fixed effects (DFE) estimators which have been widely used in empirical growth literature.

However, it is shown that in a DFE model, although the parameter estimates are consistent in terms of coefficient heterogeneity, pooled estimates are not consistent, leading to biased results. Hence DFE estimators can also produce inconsistent and potentially very misleading estimates of the average values of the parameters in dy-

${ }^{1}$ The structural shifts were identified statistically by the Clemente-Montañés-Reyes unit-root test with single growth mean shift applied to the GDP per capita growth data 1980-2013. 
namic panel data models unless the slope coefficients are identical [17]. This being the case Pesaran et al., [17] propose two estimating procedures, the Mean Group (MG) and the Pooled Mean Group (PMG) approaches that allow for a higher degree of parameter heterogeneity in growth regressions than the other estimators described above. The MG estimator allows for heterogeneity of all coefficients, intercepts and slopes, by estimating a separate equation for each country, while the coefficients for the whole panel are computed as unweighted averages of the individual coefficients. The PMG estimator considers a lower degree of heterogeneity since it imposes homogeneity in the long-run coefficients while allowing for heterogeneity in the short-run coefficients and the error variances [17]-[20].

Comparing the MG and the random or fixed effects and GMM methods, one observes that the MG estimator provides consistent estimates of the parameters' averages and provides efficient long-run estimates for a large sample size. It allows parameters to be independent across groups and does not consider homogeneity between groups. The random or fixed and GMM methods force parameters to be identical across countries which could lead to inconsistency hence misleading long-term coefficients, a problem exacerbated by long time periods [18] [21].

This being the case, the model in Equation (1) is applied to a panel dataset of African countries based on data availability, using the PMG estimation procedure to examine the short-run and long-run effects of the factors believed to be behind Africa's recent growth performance. ${ }^{2}$ The PMG takes the cointegration form of the simple autoregressive distributed lag (ARDL) model and adapts it for a panel setting by allowing the intercepts, short-run coefficients and cointegrating terms to differ across countries. As indicated above the PMG is an intermediate estimator which allows the intercepts, short run coefficients, the speed of adjustment and error variances to be different across groups, but the long run coefficients are constrained to be homogenous. This means that the PMG estimator is in between the DFE estimator and the MG estimator since it involves both pooling and averaging of the estimates [17]. Specifically the PMG assumes that error terms are serially uncorrelated and are distributed independently of the regressors (which mean explanatory variables can be treated as exogenous), there is a long-run relationship between the dependent and explanatory variables. The suitability of the PMG estimator relative to the MG estimator is tested using the Hausman test or a likelihood ratio test to assess their consistency and efficiency with reference to the pooled mean. The validity of this restriction being assessed by applying the Hausman test has the null hypothesis saying the restriction is valid. If this homogeneous coefficient restriction cannot be rejected, then there exists a long-run homogeneous relationship among countries involved in the analysis [21].

However, before the variables are tested for cointegration, they will have to be tested for stationarity using the unit root tests such as the Augmented Dickey-Fuller (ADF) test and the Pperron test, to establish their order of integration. In time series analysis two variables are said to have a long-run relationship if they are cointegrated. In case of the PMG, it is assumed that all the variables in Equation (1) are cointegrated of order 1 i.e. if they are $\mathrm{I}(1)$, then the mean $\mu_{i t}$ is an $\mathrm{I}(0)$ process for all $i$ and is independently distributed across $t$. They are also assumed to be distributed independently of the regressors. Suppose the maximum fixed lag of every variable is one, the autoregressive distributed lag, (ARDL(1,1,1) model based on Equation (1) could be defined as:

$$
\begin{aligned}
\ln Y_{i t}= & \mu_{i t}+\alpha_{10 i} \ln X_{i t}+\alpha_{11 i} \ln X_{i t-1}+\alpha_{20 i} \ln \left(Y_{i t}-X_{i t}\right) \\
& +\alpha_{21 i} \ln \left(Y_{i t}-X_{i t}\right)_{i t-1}+\alpha_{30 i} \ln Z_{i t}+\alpha_{31 i} \ln Z_{i t-1}+\lambda_{i} Y_{i t}+\varepsilon_{i}
\end{aligned}
$$

where all the variables are as defined above with $t$ as the time trend and $\varepsilon_{i t}$ as the error term. It is assumed that all these variables are I(1) and cointegrated, making the error term an I(0) process for all $i$. Based on Pesaran, Shin and Smith[17] [22], the corresponding error correction equation can be written as:

$$
\begin{aligned}
\Delta Y_{i t}= & \varphi_{i}\left[Y_{i t-1}-\theta_{0 i}-\theta_{1 i} X_{i t}-\theta_{2 i}\left(Y_{i t}-X_{i t}\right)_{i t}-\theta_{3 i} Z_{i t}\right] \\
& -\alpha_{11 i} \Delta X_{i t}-\alpha_{21 i} \Delta\left(Y_{i t}-X_{i t}\right)_{i t}-\alpha_{31 i} \Delta Z_{i t}+\varepsilon_{i t}
\end{aligned}
$$

where $\varphi_{i}=1-\lambda_{i}$; which is the adjustment coefficient; $\Delta$ is a difference operator;

$$
\theta_{0 i}=\mu_{i t} / 1-\lambda_{i}
$$

\footnotetext{
${ }^{2}$ To establish the superiority of the PMG estimation method above others like GMM, the dynamic fixed effects, mean group estimation methods etc, see Tan et al, (2006), Pesaran and Smith [18] and Pesaran et al. [22].
} 


$$
\theta_{0 i}=\frac{\mu_{i t}}{1-\lambda_{i}} ; \quad \theta_{1 i}=\frac{\alpha_{10 i}+\alpha_{11 i}}{1-\lambda_{i}} ; \quad \theta_{1 i}=\frac{\alpha_{20 i}+\alpha_{21 i}}{1-\lambda_{i}} \text { and } \theta_{1 i}=\frac{\alpha_{30 i}+\alpha_{31 i}}{1-\lambda_{i}}
$$

The error-correction speed of adjustment parameter $\varphi_{i}$, and the long-run coefficients, $\theta_{0 i} \theta_{1 i}, \theta_{2 i}$ and $\theta_{3 i}$ are the parameters of interest to be estimated. Parameter $\varphi_{i}$ is expected to be negative in order to exhibit a return to the long-run equilibrium. Theoretically all the three parameters are expected to be positive as we expect them to have a positive impact on growth. ${ }^{3}$

\subsection{Variables and Data}

While recognizing the fact that there is a wide range of factors and policy variables that theoretically and empirically affect growth, this study focuses only on those that are closely related to Africa's macroeconomic stance (especially those related to fiscal, monetary and exchange rate policies), human capital and demographic influences, investment and trade policies, especially those related to the increasing commodity prices experienced during the period understudy and Africa's emergence of new development partners.

In this paper output is captured by GDP per capita at current prices, while fiscal policy variables include external debt as a ratio of GDP, fiscal balances (cash surplus or deficits as a percentage of GDP), public and private investment, FDI as a percentage of GDP, total domestic demand captured by the gross national expenditure as a percentage of GDP, domestic credit to the private sector (\% of GDP), and monetary policy variables include inflation, real effective exchange rate, nominal and real interest rates measured by the banks' lending rate and lending rate minus inflation respectively. While trade policy variables include trade openness (exports plus imports as a ration of GDP), external terms of trade (price of exports to value of imports Px/Pm), and the internal terms of trade (price of exports to GDP deflator Px/Py)).The internal terms of trade are used as a measure of price movements because it has been argued that in order to assess the impact of external price shocks on an economy as a whole, the prices of exports and imports should be related to the prices of non-tradables as well (Bhattacharyya and Williamson 2013). To do this, a price boom (or bust) must be expressed relative to all other prices in the domestic economy in order to assess its impact on the whole economy. It is argued that the external TOT does not by itself offer an adequate measure of price booms and busts relative to the rest of the economy, and a more effective measure could therefore be Px/Py.

Human capital is measured by education variables which include primary, secondary and tertiary education enrollment ratios. Demographic influences are measured by growth in working-age population (ages 15 - 64). We also try to measure these influences through the difference between growth rate of the working-age population and that of the whole population, since it is believed that countries will have a higher per capita growth if the working-age population is growing faster than the whole population [23].

The empirical analysis in this study is based on country level panel of aggregate data over the period 19802013. The study employs unbalanced panel data from all the African countries except South Sudan despite having very short panels for some of the countries. The data for the variables such as population and primary education came from the World Bank's World Development Indicators (WDI) and the Africa Development Indicators (ADI) databases, while gross capital formation, FDI net inflows, public investment, private investment, fiscal balance, external debt, credit to the private sector, real interest rates, real exchange rates inflation, trade openness, GDP growth, GDP per capita, price of imports and exports came from the Economist Intelligence Unit (EIU).

\subsection{Statistical Summary of Variables}

In order to explain the connection between Africa's recent growth performance and the factors driving this growth, the short- and long-term trends of some of the key variables that are used in the econometric analysis proposed are reviewed. Since Africa started experiencing significant growth rates in the 2000s. Table 1 presents a statistical summary of means for these variables and their associated standard errors over the periods, 1980-99 and 2000-13. The means are significantly different between the two periods showing a relatively significant improvement over the period 2000-2013 among these variables, except public investment which has shown a decline over the period. As indicated earlier, some notable improvements are associated with GDP per capita, FDI net inflows, working age population, debt service ratio, credit to the private sector, inflation rate, trade openness,

${ }^{3}$ See Pesaran, Shin and Smith [17] for detailed information. 
internal terms of trade (Px/Py) and fiscal balances.

\section{Empirical Analysis and Results}

The paper applies the new heterogenous panel unit root tests and uses the PMG estimator proposed by Pesaran et al. [17] to estimate the short- and long-run effects of the factors driving Africa's growth. Before the analysis, we first establish the order of and verify that all variables are integrated of the same order. Since the analysis is based on unbalanced panel data, only three different panel unit root tests qualify to be used as they allow for heterogeneity in the autoregressive coefficient [24]. The appropriate lag length was arrived at using the Akaike information criteria (AIC), and the results of the different unit root tests are presented in Table 2. All the three unit root tests' results reject the hypothesis that all panels contain a unit root, indicating that there exists a fraction of panels that follow a stationary process, despite some variables such as primary education and debt showing the opposite results from the IPS and Fisher's Pperron test, respectively.

The estimation of Equation (3) is only appropriate if there is a long-run level relationship between GDP per capita and the long-run right-hand side variables. In addition, estimating Equation (2) in a single-equation framework without additional equations for the long-run right-hand side variables, is only appropriate if these variables are weakly exogenous [24].

Since the unit root tests have indicated that there exists a fraction of panels that follow a stationary processes, the next step is to determine whether a cointegrating relationship exists, and to do this the methodology developed by Pedroni [25] is applied. The methodology employs four panel statistics and three group panel statistics to test the null hypothesis of no cointegration against the alternative hypothesis of the existence of cointegration among the variables. The results in Table 3 show that there is strong evidence of panel cointegration among the variables. In the case of panel statistics, the null hypothesis is rejected by all the statistics at below $5 \%$ level of significance, meaning that the variables in the stipulated growth function are cointegrated for all the countries in the panel dataset. Similar results are obtained for all the statistics for the group panel case except for the ADF test statistic, meaning that cointegration exists among the variables at least for one of the countries. ${ }^{4}$

Having established that there is a linear combination of the variables that keeps the pooled variables in

Table 2. Results of panel unit root tests.

\begin{tabular}{|c|c|c|c|}
\hline Variable & IPS test & Fisher (Dfuller) test & Fisher (Pperron) test \\
\hline GDP per capita & $\begin{array}{l}-1,713 \\
(0.043)^{* *}\end{array}$ & All $(0.000)^{* * *}$ & $\begin{array}{l}P 140.242(0.015)^{* * *} ; Z-1.895(0.029)^{* *} \\
L^{*}-1.916(0.028)^{* *} ; P \operatorname{m} 2.352(0.009)^{* * *}\end{array}$ \\
\hline Domestic investment & $\begin{array}{l}-6.344 \\
(0.000)^{* * *}\end{array}$ & All $(0.000)^{* * *}$ & $\begin{array}{l}P 251.579(0.000)^{* * *} ; Z-7.422(0.000)^{* * *} \\
L^{*}-7.818(0.000)^{* * *} ; P \operatorname{m} 9.998(0.000)^{* * *}\end{array}$ \\
\hline FDI inflows (lag 1) & $\begin{array}{l}-10.904 \\
(0.000)^{* * *}\end{array}$ & All $(0.000)^{* * *}$ & $\begin{array}{c}P 443.116(0.000)^{* * *} ; Z-12.843(0.000)^{* * *} \\
L^{*}-15.975(0.000)^{* * *} ; P \operatorname{m~} 23.153(0.000)^{* * *}\end{array}$ \\
\hline Work-age population & $\begin{array}{l}-3.623 \\
(0.000)^{* * *}\end{array}$ & All $(0.000)^{* * *}$ & $\begin{array}{c}P 528.628(0.000)^{* * *} ; Z-7.211(0.000)^{* * *} \\
L^{*}-16.363(0.000)^{* * *} ; P \operatorname{m~} 29.026(0.000)^{* * *}\end{array}$ \\
\hline Primary education & $\begin{array}{c}3.994 \\
(1.000)\end{array}$ & All $(0.000)^{* * *}$ & $\begin{array}{l}P 215.531(0.000)^{* * *} ; Z-4.030(0.000)^{* * *} \\
L^{*}-4.256(0.000)^{* * *} ; P \operatorname{m~} 4.166(0.000)^{* * *}\end{array}$ \\
\hline Trade openness & $\begin{array}{l}-3.866 \\
(0.000)^{* * *}\end{array}$ & All $(0.000)^{* * *}$ & $\begin{array}{l}P 166.656(0.000)^{* * *} ; Z-4.030(0.000)^{* * *} \\
L^{*}-4.256(0.000)^{* * *} ; P \operatorname{m~} 4.166(0.000)^{* * *}\end{array}$ \\
\hline REER & $\begin{array}{l}-1.686 \\
(0.046)^{* *}\end{array}$ & All $(0.000)^{* * *}$ & $\begin{array}{l}P 121.403(0.030)^{* *} ; Z-1.745(0.041)^{* *} \\
L^{*}-1.858(0.032)^{* *} ; P \operatorname{m~} 1.999(0.023)^{* *}\end{array}$ \\
\hline Debt & $-1.762(0.039)^{* *}$ & All $(0.000)^{* * *}$ & $\begin{array}{c}P 96.036(0.594) ; Z 0.491(0.688) \\
L^{*} 0.586(0.721) ; P m-0.280(0.610)\end{array}$ \\
\hline Pxpm & $-4.666(0.000)^{* * *}$ & All $(0.000)^{* * *}$ & $\begin{array}{l}P 184.706(0.000)^{* * *} ; Z-4.999(0.000)^{* * *} \\
L^{*}-4.989(0.000)^{* * *} ; P m 5.406(0.000)^{* * *}\end{array}$ \\
\hline
\end{tabular}

Notes: $P, Z, L$ and $P \mathrm{~m}$ stand for inverse chi-square, inverse normal, inverse logit and modified inverse chi-squared test statistics respectively while All stands for all these statistics; and ${ }^{*},{ }^{* *}$ and ${ }^{* * *}=$ significance at 10,5 and 1 percent level respectively.

${ }^{4}$ See Pedroni [25] for more details. 
Table 3. Results of the Pedroni panel cointegration tests.

\begin{tabular}{ccc}
\hline Test statistics & Panel & Group \\
\hline Variance ratio $(V)$ & $-3.197^{* * *}$ & $6.746^{* * *}$ \\
$P$ statistic (rho) & $4.658^{* * *}$ & $-6.568^{* * *}$ \\
t-statistic (t) & $2.295^{* *}$ & 43 \\
Adf statistic (aaf) & $1.973^{* *}$ & 1281 \\
No. of panel units & & 28 \\
No. of observations & & 286 \\
\hline
\end{tabular}

Note: ${ }^{* *}$ and ${ }^{* * *}=$ significance level at $5 \%$ and $1 \%$ respectively.

proportion to each other in the long run, Equation (4) can be estimated to generate short- and long-run estimates. In view that the OLS estimator may not be appropriate as it may produce both biased and inconsistent estimates when applied to cointegrated panels, the PMG estimation method developed by Pesaran et al. [17] is utilized. As stipulated earlier, the PMG methodology also allows the utilization of the traditional dynamic fixed effects (DFE) estimator that relies on pooling of cross sections, and MG estimator that relies on averaging of cross-sections, and the PMG estimator that relies on a combination of pooling and averaging of coefficients. The model specification in Equation (4) was used to produce PMG, MG and DFE estimates in Table 4 to examine as to what extent Africa's recent growth has been affected by the underlying factors that have been identified above. The PMG model allows for heterogeneous short-run dynamics and common long-run elasticities, hence the results include both the long-run parameter estimates and the averaged short-run parameter estimates.

The results show significant variations depending on the estimation method used, from MG (the least restrictive, but potentially inefficient), to PMG and to DFE. In comparing the PMG, MG and DFE estimates, despite the differences in the magnitudes of the size of the coefficients and level of significance in the three estimation methods, the signs of these coefficients both in the estimated short- and long-run coefficients are the same. The speed of adjustment estimates from each model implies significantly different short-run dynamics $(0.09$ from PMG, 0.34 from MG and 0.08 from DFE). Recall that the PMG estimator constrains the long-run coefficients to be equal across all panels (pooling), which yields efficient and consistent estimates when the restrictions are true. However, this hypothesis of slope homogeneity is usually empirically rejected, and if rejected the PMG estimates are inconsistent. However, the MG estimates are consistent in either case [20].

The DFE estimator, like the PMG estimator, restricts the coefficients of the cointegrating vector to be equal across all panels. It further restricts the speed of adjustment coefficient and the short-run coefficients to be equal. Hence we perform the Hausman test to test the difference in these models and ascert the most appropriate model between them [20]. With regard to the DFE models, the Hausman test is used in the analysis to measure the extent of endogeneity since DFE models are subject to a simultaneous equation bias as a result of the endogeneity between the error term and the lagged dependent variable [26]. The results of the Hausman test between PMG and MG indicate that the null hypothesis of having systematic difference in coefficients (MG) is rejected at below the $1 \%$ level of significance, hence the PMG model is preferred. While performing the Hausman test to measure extent of endogeneity shows that the simultaneous bias is minimal for the MG and DFE models, hence the DFE model is preferred over the MG model. A similar result was obtained when the Hausman test was used to measure the extent of endogeneity between PMG and DFE models, making the DFE a preferred model over both PMG and MG models. However, DFE models are associated with relatively high incidences of inconsistency and biasedness as stipulated above (as the estimates are inconsistent and misleading with pooled estimates). This means that the discussion with regard to the factors influencing recent Africa's growth will be based on the preferred PMG model estimates.

Table 4 shows that the results of the variables representing the commonly used variables in estimation of growth models (e.g. population, physical and human capital) are found to have the relevant signs as predicted by economic theory. In most instances their results are observed to be robust to the inclusion of some control variables. The results of the PMG estimates in Table 6 suggest that in the short-run Africa's growth has been influenced by investment through gross capital formation growth and favorable macroeconomic conditions through 
Table 4. Estimation results: Identifying the model for the data generation process.

\begin{tabular}{|c|c|c|c|}
\hline Variables & PMG & MG & DFE \\
\hline \multicolumn{4}{|c|}{ Estimates of long-run coefficients } \\
\hline Capital formation & $\begin{array}{c}0.075 \\
(0.029)^{* * *}\end{array}$ & $\begin{array}{l}0.066 \\
(0.186)\end{array}$ & $\begin{array}{l}0.087 \\
(0.130)\end{array}$ \\
\hline Population 15 - 64 & $\begin{array}{c}0.779 \\
(0.089)^{* * *}\end{array}$ & $\begin{array}{l}1.234 \\
(0.487)^{* * *}\end{array}$ & $\begin{array}{c}1.043 \\
(0.225)^{* * *}\end{array}$ \\
\hline Trade openness & $\begin{array}{c}0.275 \\
(0.080)^{* * *}\end{array}$ & $\begin{array}{c}1.081 \\
(1.111)\end{array}$ & $\begin{array}{c}0.412 \\
(0.229)^{*}\end{array}$ \\
\hline REER $(1997=100)$ & $\begin{array}{l}0.151 \\
(0.045)^{* * *}\end{array}$ & $\begin{array}{l}1.338 \\
(0.891)\end{array}$ & $\begin{array}{c}0.163 \\
(0.126)\end{array}$ \\
\hline External debt & $\begin{array}{l}-0.337 \\
(0.028)^{* * *}\end{array}$ & $\begin{array}{l}0.110 \\
(0.366)\end{array}$ & $\begin{array}{l}-0.467 \\
(0.077)^{* * *}\end{array}$ \\
\hline Fiscal balance & $\begin{array}{l}0.167 \\
(0.031)^{* * *}\end{array}$ & $\begin{array}{c}0.042 \\
(0.097)\end{array}$ & $\begin{array}{c}0.025 \\
(0.053)\end{array}$ \\
\hline \multicolumn{4}{|c|}{ Estimates of short-run coefficients } \\
\hline Error-correction term & $\begin{array}{l}-0.089 \\
(0.026)^{* * *}\end{array}$ & $\begin{array}{l}-0.341 \\
(0.064)^{* * *}\end{array}$ & $\begin{array}{l}-0.080 \\
(0.013)^{* * *}\end{array}$ \\
\hline Capital formation & $\begin{array}{l}0.063 \\
(0.023)^{* * *}\end{array}$ & $\begin{array}{l}-0.029 \\
(0.039)\end{array}$ & $\begin{array}{l}0.031 \\
(0.013)^{* * *}\end{array}$ \\
\hline Population 15-64 & $\begin{array}{l}-0.893 \\
(0.506)^{*}\end{array}$ & $\begin{array}{l}-3.032 \\
(1.908)\end{array}$ & $\begin{array}{l}-0.482 \\
(0.356)\end{array}$ \\
\hline Trade openness & $\begin{array}{l}-0.111 \\
(0.041)^{* * *}\end{array}$ & $\begin{array}{l}-0.137 \\
(0.063)^{* *}\end{array}$ & $\begin{array}{l}-0.205 \\
(0.024)^{* * *}\end{array}$ \\
\hline $\operatorname{REER}(1997=100)$ & $\begin{array}{c}0.379 \\
(0.0677)^{* * *}\end{array}$ & $\begin{array}{l}0.309 \\
(0.081)^{* * *}\end{array}$ & $\begin{array}{l}0.057 \\
(0.016)^{* * *}\end{array}$ \\
\hline External debt & $\begin{array}{l}-0.292 \\
(0.041)^{* * *}\end{array}$ & $\begin{array}{l}-0.205 \\
(0.039)^{* * *}\end{array}$ & $\begin{array}{l}-0.314 \\
(0.0147)^{* * *}\end{array}$ \\
\hline Fiscal balance & $\begin{array}{l}0.026 \\
(0.031)\end{array}$ & $\begin{array}{c}0.020 \\
(0.029)\end{array}$ & $\begin{array}{c}0.003 \\
(0.006)\end{array}$ \\
\hline Constant & $\begin{array}{l}-0.563 \\
(0.165)^{* * * *}\end{array}$ & $\begin{array}{l}-0.941 \\
(2.522)\end{array}$ & $\begin{array}{l}-0.780 \\
(0.301)^{* * * *}\end{array}$ \\
\hline Hausman test & $X^{2}(6)=2.97(0.8123)$ & $X^{2}(6)=0.00(1.0000)$ & $\begin{array}{c}\text { G vs DFE } \\
\mathrm{X}^{2}(6)=0.11(1.0000)\end{array}$ \\
\hline
\end{tabular}

Note: ${ }^{* * *}$ and ${ }^{* * *}=$ significance level at $10 \%, 5 \%$ and $1 \%$ respectively; and values in parentheses are standard errors.

stable REER and improved fiscal balances which the continent experienced over the period. The external TOT are found to have a significant impact on growth, influenced by increases in commodity exports. However, the results show also that trade openness, fiscal balances, working-age population and foreign debt have negatively weighed on growth in the short-run.

In the long-run the results from the PMG model, in Table 4 suggest that, apart from the positive influence from the variables that have a positive effect on growth in the short-run, demographic changes and trade openness have also had a highly significant impact on growth in the long-run, signigying the role played by the growing middle class and favourable TOT influenced by increases in commodity exports. The results also show the impact of improvements in the countries' fiscal management, supported by the positive and highly significant impact of fiscal balances on growth. However, as was the case in the short-run, the impact of foreign debt continued to weigh negatively on growth even in the long-run. The analysis then proceeds by presenting the results of the impact of specific policy variables by extending the PMG basic model to include fiscal and investment variables, monetary and trade variables, and human capital and demographic influences. It should be noted 
that these policy variables' results are presented in the subsections below, and include only a set of variables deemed to have had an impact on Africa's recent growth performance.

\subsection{Fiscal and Investment Policy Variables}

Taking a closer look at specific fiscal policy variables, Table 5 shows that the coefficients for fiscal balances are positive and insignificant at conventional levels in the short-run but positive and highly significant at $1 \%$ in the long-run. This could be the effect of the strict expenditure controls and improved institutional arrangements employed over the period in most African countries-fiscal consolidation. Mainly to reduce budget deficits and prevent their monetization, with the aim of controlling inflation rates and directing expenditures towards the countries' priority sectors that have a significant and positive impact on growth.

The other variable capturing the fiscal policy strategies is the external debt as a ratio of GDP. External debt is found to exert a persistent and statistically significant negative impact on growth of African economies both in the short- and the long-run over the period under study. Despite the significant decline in debt as depicted in Figure 1, external debt still remains a detrimental factor in maintaining Africa's recent growth, calling for concerted efforts towards enhancing the development and implementation of innovative domestic resource mobilization strategies while reducing the countries' reliance on external aid.

In terms of the investment policy variables, the results show that both public and private investments have a negative and statistically significant impact on growth in the short-run, but with only private investment having a significant impact in the long-run. The results show that, when external debt is included in the model, only public investment is found to be negative and statistically significant at $1 \%$ level, signifying the detrimental role that external debt financing has on growth, as it robes African economies of the resources that could enhance effective public investments that could have a significant impact on the countries' productivity and growth. However, public investment is found to be insignificant when fiscal balances are included in the model, which could be suggesting that most of the domestic resources (public expenditures) are directed towards economic activities having minimal contribution to growth e.g. consumption expenditures through increases in public servants salaries and subsidies.

Surprisingly, FDI net inflows are found to have a negative and significant impact on growth in the long-run, suggesting that, FDI despite being beneficial to most countries, and despite frontier market countries ${ }^{5}$ attracting an increasing amount of FDI recently, it's impact on productivity and growth remains limited in most African countries [1]. This could be due to the increased shares of capital flows into resource rich countries and especially the extractive sectors which do not have the potential to create more jobs, hence having minimal impact on growth [4] [27] [28].

Empirical evidence suggests that most of the African countries might not have reached some threshold in terms of development capacity that is needed to benefit from FDI, hence it has been suggested that enhancing human capital and technological capacity could be key in reaping development benefits from FDI [1]. To capture this, the model is extended to include some human capital variables to assess their contribution towards the impact of FDI on growth.

Results in Table 5, show that in the long-run it is only secondary education that is associated with a positive and significant impact of FDI on growth, while tertiary education is associated with a negative and significant impact of FDI on growth, with primary education being associated with a positive and insignificant impact of FDI on growth. These results suggest that despite efforts being undertaken by African countries to enhance education capacities especially in primary and tertiary education, education is not providing the necessary capacity to fully utilize what FDI brings in order to have a positive but significant impact on growth. Suggesting that tertiary and primary education in Africa do not provide the necessary human capital and technological capacity to reap the benefits that come with FDI.

Both in the short- and long-run, demand is found to have a statistically insignificant impact on growth at conventional levels, depicting, to some extent, the effect of the tight monetary and fiscal policies pursued by most African countries to control inflation hence reducing demand and negatively affecting growth, as the increase in domestic demand has mainly been driven by a growing population and rising remittances with increased expenditures on consumption rather than productive investments. This could also be suggesting that the growing

${ }^{5}$ Frontier market countries such as Ghana, Uganda and Zambia have attracted increased FDI into non-mining and services sectors such as telecommunications and banking. 
Table 5. PMG short- and long-run estimates of fiscal and investment policies in, 1980-2013.

\begin{tabular}{|c|c|c|c|c|c|c|c|c|c|}
\hline Variables & (1) & (2) & (3) & (4) & (5) & (6) & (7) & (8) & (9) \\
\hline \multicolumn{10}{|l|}{$\begin{array}{l}\text { Long-run } \\
\text { estimates }\end{array}$} \\
\hline Capital formation & $\begin{array}{l}0.932 \\
(0.170)^{* * * *}\end{array}$ & $\begin{array}{l}0.866 \\
(0.100)^{* * *}\end{array}$ & $\begin{array}{l}1.159 \\
(0.198)^{* * * *}\end{array}$ & $\begin{array}{l}0.464 \\
(0.064)^{* * * *}\end{array}$ & & & & $\begin{array}{l}0.072 \\
(0.029)^{* * *}\end{array}$ & $\begin{array}{l}0.124 \\
(0.034)^{* * * *}\end{array}$ \\
\hline Population 15-64 & $\begin{array}{l}3.336 \\
(0.201)^{* * *}\end{array}$ & $\begin{array}{l}1.851 \\
(0.151)^{* * *}\end{array}$ & $\begin{array}{l}3.625 \\
(0.229)^{* * *}\end{array}$ & $\begin{array}{l}1.919 \\
(0.150)^{* * *}\end{array}$ & & & & $\begin{array}{l}-0.031 \\
(0.121)\end{array}$ & $\begin{array}{c}0.492 \\
(0.105)^{* * *}\end{array}$ \\
\hline Trade & $\begin{array}{c}0.125 \\
(0.181)\end{array}$ & $0.119(0.110)$ & $\begin{array}{c}0.395 \\
(0.209)^{* *}\end{array}$ & $\begin{array}{l}-0.016) \\
(0.085)\end{array}$ & $\begin{array}{c}0.077 \\
(0.070)\end{array}$ & $\begin{array}{l}0.826 \\
(0.211)^{* * *}\end{array}$ & $\begin{array}{c}0.675 \\
(0.109)^{* * *}\end{array}$ & $\begin{array}{c}0.164 \\
(0.071)^{* *}\end{array}$ & \\
\hline $\begin{array}{c}\text { REER } \\
(1997=100)\end{array}$ & $\begin{array}{l}-0.062 \\
(0.140)\end{array}$ & $0.099(0.077)$ & $\begin{array}{l}-0.110 \\
(0.157)\end{array}$ & $\begin{array}{c}0.083 \\
(0.079)\end{array}$ & $\begin{array}{c}0.018 \\
(0.044)\end{array}$ & $\begin{array}{l}0.883 \\
(0.134)^{* * *}\end{array}$ & $\begin{array}{l}-0.064 \\
(0.085)\end{array}$ & $\begin{array}{l}-0.151 \\
(0.054)^{* * *}\end{array}$ & $\begin{array}{c}0.158 \\
(0.038)^{* * *}\end{array}$ \\
\hline External debt & & $\begin{array}{l}-0.264 \\
(0.033)^{* * *}\end{array}$ & & $\begin{array}{l}-0.252 \\
(0.032)^{* * *}\end{array}$ & $\begin{array}{l}-0.288 \\
(0.026)^{* * *}\end{array}$ & $\begin{array}{l}-0.152 \\
(0.079)^{* * * *}\end{array}$ & $\begin{array}{l}-0.203 \\
(0.039)^{* * *}\end{array}$ & $\begin{array}{l}-0.423 \\
(0.029)^{* * *}\end{array}$ & \\
\hline Fiscal balance & & & $0.014(.022)$ & $\begin{array}{l}-0.023 \\
(0.016)\end{array}$ & $\begin{array}{l}-0.089 \\
(0.017)^{* * *}\end{array}$ & $\begin{array}{c}0.294 \\
(0.051)^{* * *}\end{array}$ & $\begin{array}{l}-0.009 \\
(0.012)\end{array}$ & $\begin{array}{l}0.200 \\
(0.029)^{* * *}\end{array}$ & $\begin{array}{c}0.088 \\
(0.030)^{* * * *}\end{array}$ \\
\hline Public investment & $\begin{array}{l}-0.026 \\
(0.087)\end{array}$ & $\begin{array}{l}-0.208 \\
(0.051)^{* * *}\end{array}$ & $\begin{array}{c}0.012 \\
(0.097)\end{array}$ & & & & & & \\
\hline Private investment & $\begin{array}{l}-0.205 \\
(0.099)^{* *}\end{array}$ & $\begin{array}{l}-0.212 \\
(0.058)^{* * *}\end{array}$ & $\begin{array}{l}-0.270 \\
(0.107)^{* * *}\end{array}$ & & & & & & \\
\hline FDI net inflows & & & & $\begin{array}{l}-0.020 \\
(0.009)^{* *}\end{array}$ & $\begin{array}{c}0.012 \\
(0.013)\end{array}$ & $\begin{array}{l}0.071 \\
(0.029)^{* * *}\end{array}$ & $\begin{array}{l}-0.066 \\
(0.020)^{* * *}\end{array}$ & & \\
\hline Primary & & & & & $\begin{array}{l}0.532 \\
(0.070)^{* * *}\end{array}$ & & & & $\begin{array}{l}0.445 \\
(0.115)^{* * *}\end{array}$ \\
\hline Secondary & & & & & & $\begin{array}{l}0.182 \\
(0.032)^{* * * *}\end{array}$ & & & \\
\hline Tertiary & & & & & & & $\begin{array}{l}0.539 \\
(0.030)^{* * *}\end{array}$ & & \\
\hline Demand & & & & & & & & $\begin{array}{c}0.242 \\
(0.197)\end{array}$ & \\
\hline Dummy & & & & & & & & & $\begin{array}{c}0.913 \\
(0.141)^{* * * *}\end{array}$ \\
\hline \multicolumn{10}{|l|}{$\begin{array}{l}\text { Short-run } \\
\text { estimates }\end{array}$} \\
\hline $\begin{array}{l}\text { Error-correction } \\
\text { term }\end{array}$ & $\begin{array}{l}-0.065 \\
(0.015)^{* * *}\end{array}$ & $\begin{array}{l}-0.072 \\
(0.020)^{* * *}\end{array}$ & $\begin{array}{l}-0.054 \\
(0.015)^{* * *}\end{array}$ & $\begin{array}{l}-0.081 \\
(0.023)^{* * *}\end{array}$ & $\begin{array}{l}-0.091 \\
(0.030)^{* * *}\end{array}$ & $\begin{array}{l}-0.027 \\
(0.013)^{* *}\end{array}$ & $\begin{array}{l}-0.064 \\
(0.020)^{* * *}\end{array}$ & $\begin{array}{l}-0.088 \\
(0.027)^{* * *}\end{array}$ & $\begin{array}{l}-0.207 \\
(0.031)^{* * *}\end{array}$ \\
\hline $\begin{array}{c}\text { Capital } \\
\text { investment }\end{array}$ & $\begin{array}{c}0.062 \\
(0.048)\end{array}$ & $0.037(0.046)$ & $\begin{array}{c}0.079 \\
(0.044)^{*}\end{array}$ & $\begin{array}{c}0.041 \\
(0.023)^{*}\end{array}$ & $\begin{array}{l}-0.010 \\
(0.004)^{* * *}\end{array}$ & & & $\begin{array}{l}0.096 \\
(0.029)^{* * *}\end{array}$ & $\begin{array}{l}-0.031 \\
(0.035)\end{array}$ \\
\hline $\begin{array}{l}\text { Population } \\
15-64\end{array}$ & $\begin{array}{c}0.468 \\
(0.541)\end{array}$ & $\begin{array}{l}-0.933 \\
(0.533)^{*}\end{array}$ & $\begin{array}{c}0.629 \\
(0.490)\end{array}$ & $\begin{array}{l}-1.197 \\
(0.488)^{* * * *}\end{array}$ & & & & $\begin{array}{c}-0.746 \\
0.521\end{array}$ & $\begin{array}{l}-0.360 \\
(0.638)\end{array}$ \\
\hline Trade & $\begin{array}{l}-0.163 \\
(0.045)^{* * *}\end{array}$ & $\begin{array}{l}-0.121 \\
(0.045)^{* * *}\end{array}$ & $\begin{array}{l}-0.148 \\
(0.044)^{* * *}\end{array}$ & $\begin{array}{l}-0.113 \\
(0.049)^{* *}\end{array}$ & $\begin{array}{l}-0.060 \\
(0.039)\end{array}$ & $\begin{array}{l}-0.047 \\
(0.042)\end{array}$ & $\begin{array}{l}-0.088 \\
(0.039)^{* *}\end{array}$ & $\begin{array}{l}-0.114 \\
(0.046)^{* * *}\end{array}$ & \\
\hline $\begin{array}{c}\text { REER } \\
(1997=100)\end{array}$ & $\begin{array}{l}0.578 \\
(0.068)^{* * *}\end{array}$ & $\begin{array}{c}0.393 \\
(0.067)^{* * *}\end{array}$ & $\begin{array}{l}0.585 \\
(0.069)^{* * *}\end{array}$ & $\begin{array}{l}0.400 \\
(0.072)^{* * *}\end{array}$ & $\begin{array}{l}0.421 \\
(0.061)^{* * *}\end{array}$ & $\begin{array}{l}0.377 \\
(0.062)^{* * *}\end{array}$ & $\begin{array}{l}0.399 \\
(0.062)^{* * *}\end{array}$ & $\begin{array}{c}0.421 \\
0.073^{* * *}\end{array}$ & $\begin{array}{c}0.656 \\
(0.092)^{* * *}\end{array}$ \\
\hline External debt & & $\begin{array}{l}-0.308 \\
(0.040)^{* * *}\end{array}$ & & $\begin{array}{l}-0.287 \\
(0.040)^{* * *}\end{array}$ & $\begin{array}{l}-0.284 \\
(0.037)^{* * *}\end{array}$ & $\begin{array}{l}-0.319 \\
(0.036)^{* * *}\end{array}$ & $\begin{array}{l}-0.299 \\
(0.034)^{* * *}\end{array}$ & $\begin{array}{l}-0.295 \\
(0.041)^{* * *}\end{array}$ & \\
\hline Fiscal balance & & & $\begin{array}{c}0.029 \\
(0.030)\end{array}$ & $\begin{array}{c}0.024 \\
(0.027)\end{array}$ & $\begin{array}{c}0.049 \\
(0.040)\end{array}$ & $\begin{array}{c}0.040 \\
(0.046)\end{array}$ & $\begin{array}{c}0.031 \\
(0.026)\end{array}$ & $\begin{array}{l}-0.005 \\
(0.006)\end{array}$ & $\begin{array}{c}0.012 \\
(0.021)\end{array}$ \\
\hline $\begin{array}{c}\text { Public } \\
\text { investment }\end{array}$ & $\begin{array}{l}-0.061 \\
(0.028)^{* *}\end{array}$ & $0.007(0.027)$ & $\begin{array}{l}-0.069 \\
(0.025)^{* * *}\end{array}$ & & & & & & \\
\hline $\begin{array}{c}\text { Private } \\
\text { investment }\end{array}$ & $\begin{array}{l}-0.070 \\
(0.043)^{*}\end{array}$ & $\begin{array}{l}-0.022 \\
(0.036)\end{array}$ & $\begin{array}{l}-0.075 \\
(0.040)^{*}\end{array}$ & & & & & & \\
\hline $\begin{array}{l}\text { FDI net } \\
\text { inflows }\end{array}$ & & & & $\begin{array}{l}-0.005 \\
(0.004)\end{array}$ & & $\begin{array}{l}-0.010 \\
(0.004)^{* * *}\end{array}$ & $\begin{array}{l}-0.006 \\
(0.004)^{*}\end{array}$ & & \\
\hline
\end{tabular}




\section{Continued}

\begin{tabular}{|c|c|c|c|c|c|c|c|c|c|}
\hline Primary & & & & & $\begin{array}{c}-0.0438 \\
(0.107)\end{array}$ & & & & $\begin{array}{l}-0.302 \\
(0.220)\end{array}$ \\
\hline Secondary & & & & & & $\begin{array}{c}0.039 \\
(0.038)\end{array}$ & & & \\
\hline Tertiary & & & & & & & $\begin{array}{l}-0.004 \\
(0.019)\end{array}$ & & \\
\hline Demand & & & & & & & & $\begin{array}{l}-0.149 \\
(0.124)\end{array}$ & \\
\hline Dummy & & & & & & & & & $\begin{array}{c}-0.096 \\
(0.023)^{* * *}\end{array}$ \\
\hline Constant & $\begin{array}{c}-3.098 \\
(0.718)^{* * *}\end{array}$ & $\begin{array}{l}-1.692 \\
(0.491)^{* * *}\end{array}$ & $\begin{array}{l}-2.921 \\
(0.816)^{* * *}\end{array}$ & $\begin{array}{c}-1.899 \\
(0.511)^{* * *}\end{array}$ & $\begin{array}{c}0.429 \\
(0.136)^{* * *}\end{array}$ & $\begin{array}{l}-0.006 \\
(0.017)\end{array}$ & $\begin{array}{c}0.293 \\
(0.082)^{* * * *}\end{array}$ & $\begin{array}{c}0.655 \\
(0.196)^{* * *}\end{array}$ & $\begin{array}{l}-0.839 \\
(0.142)^{* * *}\end{array}$ \\
\hline No. of obs. & 1334 & 1239 & 1334 & 1228 & 1207 & 1241 & 1241 & 1241 & 1304 \\
\hline No. of groups & 47 & 44 & 47 & 44 & 43 & 44 & 44 & 44 & 46 \\
\hline
\end{tabular}

Note: ${ }^{*},{ }^{* *}$ and ${ }^{* * *}=$ significance level at $10 \%, 5 \%$ and $1 \%$ respectively; and values in parentheses are standard errors.

working-age population does not have the capacity to influence demand for goods and services as a greater proportion of it is unemployed or employed in sectors with relatively low productivity such as the agricultural and services sector.

The results from Table 5 show also that other policies/factors and strategies (such as institutional and regulatory reforms) captured by the dummy variable indicate that despite having a negative impact on growth in the short-run, they lead to a significant positive influence on growth in the long-run. This calls for the maintenance and enhancement of the institutional and regulatory reforms, as well as peace and security that are being implemented and pursued in many African countries.

\subsection{Monetary and Trade Policies}

In terms of monetary policy, both the short- and long-run coefficients of the REER are positive and statistically significant at $1 \%$ level, which could be signifying the effects of the floatation of the exchange rates in most countries, hence enhancing their exportats (Table 6). Looking at other monetary policy variables, Table 6 shows that the short-run coefficient for inflation is negative and statistically insignificant, while it is negative and highly significant at $1 \%$ in the long-run. As a monetary policy tool, the short-run coefficient for the real interest rate is negative and statistically significant at $1 \%$ level, while it is positive and statistically significant at $1 \%$ level in the long-run. However, the results seem to suggest that growth seems not to be more responsive to nominal interest rate as they are found to be negative but insignificant both in the short- and long-run.

The results of the impact of the real interest rate on growth are in line with the results obtained when credit to the private sector is used in the model. The results show a negative and significant impact in the short run but positive and significant over the long-run. To some extent suggesting that despite the relatively high costs of borrowing having detrimental effects on growth in the short-run, they lead to positive growth effects in the long-run as funds are invested in more productive sectors. However, it is interesting to note that out of the 52 countries used in the analysis, 31 had interest rates less than or equal to 15\% by 2010, of which 11 countries had their interest rates less than or equal to $10 \%$, as compared to only 13 countries having their interest rates below or equal to $15 \%$ in 2000 with only 4 having their interest rates below or equal to $10 \%$ Though contrary to our results, this could have enhanced the provision of credit to the private sector. Money supply is found to have a negative and significant impact on growth at $1 \%$ level in the short-run but insignificant in the long-run.

With regard to trade policy, trade openness is found to have a negative and significant impact on growth in the short-run but with a positive and significant impact in the long-run (Table 4). When trade openness is replaced with external TOT (Px/Pm), they are found to be negative and significant in the short-run but positive and highly significant in the long-run. This result might be suggesting that the favourable terms of trade due to rising commodity prices experienced over the period led to an increase in both the rate of capital accumulation and efficiency or intensity with which factors of production are used (see IMF, 1998). Since a greater proportion of Africa's exports are raw commodities, we could easily generalize that the short-run dynamics of the commodity 
Table 6. PMG short-run and long-run estimates of the effects of monetary and trade policies in Africa, 1980-2013.

\begin{tabular}{|c|c|c|c|c|c|c|c|c|}
\hline Variables & (1) & (2) & (3) & (4) & (5) & (6) & (7) & (8) \\
\hline \multicolumn{9}{|l|}{$\begin{array}{l}\text { Long-run } \\
\text { estimates }\end{array}$} \\
\hline Capital formation & $\begin{array}{l}0.444 \\
(0.059)^{* * *}\end{array}$ & $\begin{array}{l}0.168 \\
(0.047)^{* * *}\end{array}$ & $\begin{array}{c}0.268 \\
(0.051)^{* * * *}\end{array}$ & $\begin{array}{c}0.228 \\
(0.052)^{* * * *}\end{array}$ & $\begin{array}{l}0.270 \\
(0.052)^{* * *}\end{array}$ & $\begin{array}{c}0.415 \\
(0.048)^{* * *}\end{array}$ & $\begin{array}{l}0.288 \\
(0.043)^{* * *}\end{array}$ & $\begin{array}{c}0.120 \\
(0.037)^{* * *}\end{array}$ \\
\hline Population 15 - 64 & $\begin{array}{c}1.350 \\
(0.103)^{* * *}\end{array}$ & $\begin{array}{l}1.118 \\
(0.066)^{* * *}\end{array}$ & $\begin{array}{l}1.283 \\
(0.092)^{* * *}\end{array}$ & $\begin{array}{l}0.756 \\
(0.058)^{* * *}\end{array}$ & $(0.082)^{* * *}$ & $\begin{array}{l}0.659 \\
(0.073)^{* * *}\end{array}$ & $\begin{array}{l}0.236 \\
(0.076)^{* * *}\end{array}$ & $\begin{array}{c}0.872 \\
(0.075)^{* * *}\end{array}$ \\
\hline Trade & $\begin{array}{c}0.005 \\
(0.066)\end{array}$ & $\begin{array}{l}0.286 \\
(0.080)^{* * *}\end{array}$ & $\begin{array}{l}0.371 \\
(0.090)^{* * *}\end{array}$ & $\begin{array}{l}0.416 \\
(0.098)^{* * *}\end{array}$ & $\begin{array}{c}0.084 \\
(0.084)\end{array}$ & & & \\
\hline External debt & $\begin{array}{c}-0.270 \\
(0.023)^{* * *}\end{array}$ & $\begin{array}{l}-0.310 \\
(0.017)^{* * *}\end{array}$ & $\begin{array}{l}-0.241 \\
(0.021)^{* * * *}\end{array}$ & $\begin{array}{l}-0.411 \\
(0.030)^{* * *}\end{array}$ & $\begin{array}{c}-0.368 \\
(0.026)^{* * *}\end{array}$ & $\begin{array}{l}-0.558 \\
(0.034)^{* * * *}\end{array}$ & $\begin{array}{l}-0.462 \\
(0.032)^{* * *}\end{array}$ & $\begin{array}{l}-0.191 \\
(0.025)^{* * *}\end{array}$ \\
\hline Fiscal balance & $\begin{array}{l}-0.027 \\
(0.018)\end{array}$ & $\begin{array}{l}-0.025 \\
(0.017)\end{array}$ & $\begin{array}{l}0.065 \\
(0.020)^{* * * *}\end{array}$ & $\begin{array}{l}0.124 \\
(0.025)^{* * * *}\end{array}$ & $\begin{array}{l}-0.080 \\
(0.019)^{* * *}\end{array}$ & $\begin{array}{l}0.100 \\
(0.026)^{* * *}\end{array}$ & $\begin{array}{l}0.085 \\
(0.026)^{* * *}\end{array}$ & $\begin{array}{c}0.032 \\
(0.020)\end{array}$ \\
\hline Inflation & $\begin{array}{l}-0.065 \\
(0.020)^{* * *}\end{array}$ & & & & & & & \\
\hline Real interest rate & & $\begin{array}{l}0.127 \\
(0.015)^{* * *}\end{array}$ & & & & & & \\
\hline $\begin{array}{l}\text { Nominal interest } \\
\text { rate }\end{array}$ & & & $\begin{array}{l}-0.812 \\
(0.080)\end{array}$ & & & & & \\
\hline $\begin{array}{l}\text { Credit to private } \\
\text { sector }\end{array}$ & & & & $\begin{array}{l}0.152 \\
(0.040)^{* * * *}\end{array}$ & & & & \\
\hline Money supply (M2) & & & & & $\begin{array}{c}0.066 \\
(0.072)\end{array}$ & & & \\
\hline $\begin{array}{l}\text { External TOT } \\
\quad(\mathrm{PxPm})\end{array}$ & & & & & & $\begin{array}{l}0.089 \\
0.038^{* *}\end{array}$ & & \\
\hline $\begin{array}{l}\text { Internal TOT } \\
\text { (PxPy) }\end{array}$ & & & & & & & $\begin{array}{c}0.280 \\
0.026^{* * *}\end{array}$ & \\
\hline $\begin{array}{l}\text { Internal TOT } \\
\text { (PmPy) }\end{array}$ & & & & & & & & $\begin{array}{c}0.336 \\
(0.028)^{* * *}\end{array}$ \\
\hline \multicolumn{9}{|l|}{$\begin{array}{l}\text { Short-run } \\
\text { estimates }\end{array}$} \\
\hline $\begin{array}{c}\text { Error-correction } \\
\text { term }\end{array}$ & $\begin{array}{l}-0.119 \\
(0.022)^{* * *}\end{array}$ & $\begin{array}{l}-0.115 \\
(0.022)^{* * *}\end{array}$ & $\begin{array}{l}-0.108 \\
(0.020)^{* * *}\end{array}$ & $\begin{array}{l}-0.115 \\
(0.021)^{* * *}\end{array}$ & $\begin{array}{l}-0.126 \\
(0.018)^{* * *}\end{array}$ & $\begin{array}{l}-0.116 \\
(0.019)^{* * *}\end{array}$ & $\begin{array}{l}-0.109 \\
(0.021)^{* * *}\end{array}$ & $\begin{array}{l}-0.110 \\
(0.022)^{* * *}\end{array}$ \\
\hline Capital formation & $\begin{array}{c}0.029 \\
(0.024)\end{array}$ & $\begin{array}{l}0.049 \\
(0.024)^{* * *}\end{array}$ & $\begin{array}{c}0.045 \\
(0.026)^{*}\end{array}$ & $\begin{array}{c}0.046 \\
(0.025)^{*}\end{array}$ & $\begin{array}{c}0.031 \\
(0.023)\end{array}$ & $\begin{array}{l}-0.007 \\
(0.023)\end{array}$ & $\begin{array}{c}0.021 \\
(0.021)\end{array}$ & $\begin{array}{l}-0.047 \\
(0.027)^{*}\end{array}$ \\
\hline Population 15 - 64 & $\begin{array}{l}-1.148 \\
(0.451)^{* * * *}\end{array}$ & $\begin{array}{l}-0.965 \\
(0.486)^{* *}\end{array}$ & $\begin{array}{l}-0.739 \\
(0.427)^{*}\end{array}$ & $\begin{array}{l}-0.867 \\
(0.386)^{* *}\end{array}$ & $\begin{array}{l}-0.968 \\
(0.439)^{* *}\end{array}$ & $\begin{array}{l}-0.978 \\
(0.466)^{* *}\end{array}$ & $\begin{array}{l}-0.962 \\
(0.447)^{* * *}\end{array}$ & $\begin{array}{l}-0.880 \\
(0.420)^{* *}\end{array}$ \\
\hline Trade openness & $\begin{array}{l}-0.268 \\
(0.034)^{* * * *}\end{array}$ & $\begin{array}{l}-0.290 \\
(0.037)^{* * *}\end{array}$ & $\begin{array}{l}-0.283 \\
(0.034)^{* * *}\end{array}$ & $\begin{array}{l}-0.255 \\
(0.036)^{* * *}\end{array}$ & $\begin{array}{l}-0.246 \\
(0.035)^{* * *}\end{array}$ & & & \\
\hline External debt & $\begin{array}{c}-0.324 \\
(0.034)^{* * *}\end{array}$ & $\begin{array}{c}-0.313 \\
(0.035)^{* * *}\end{array}$ & $\begin{array}{l}-0.322 \\
(0.032)^{* * *}\end{array}$ & $\begin{array}{l}-0.314 \\
(0.035)^{* * *}\end{array}$ & $\begin{array}{c}-0.308 \\
(0.035)^{* * *}\end{array}$ & $\begin{array}{l}-0.318 \\
(0.035)^{* * *}\end{array}$ & $\begin{array}{l}-0.306 \\
(0.034)^{* * *}\end{array}$ & $\begin{array}{l}-0.311 \\
(0.032)^{* * * *}\end{array}$ \\
\hline Fiscal balance & $\begin{array}{l}-0.002 \\
(0.006)\end{array}$ & $\begin{array}{c}0.003 \\
(0.007)\end{array}$ & $\begin{array}{l}-0.001 \\
(0.008)\end{array}$ & $\begin{array}{l}-0.011 \\
(0.007)\end{array}$ & $\begin{array}{c}-0.0003 \\
(0.008)\end{array}$ & $\begin{array}{c}0.013 \\
(0.017)\end{array}$ & $\begin{array}{c}0.007 \\
(0.014)\end{array}$ & $\begin{array}{c}0.014 \\
(0.015)\end{array}$ \\
\hline Inflation & $\begin{array}{l}-0.004 \\
(0.003)\end{array}$ & & & & & & & \\
\hline Real interest rate & & $\begin{array}{c}-0.019 \\
(0.004)^{* * *}\end{array}$ & & & & & & \\
\hline $\begin{array}{l}\text { Nominal interest } \\
\text { rate }\end{array}$ & & & $\begin{array}{l}-0.007 \\
(0.023)\end{array}$ & & & & & \\
\hline $\begin{array}{l}\text { Credit to private } \\
\text { sector }\end{array}$ & & & & $\begin{array}{l}-0.048 \\
(0.022)^{* *}\end{array}$ & & & & \\
\hline
\end{tabular}




\section{Continued}

\begin{tabular}{|c|c|c|c|c|c|c|c|c|}
\hline Money supply (M2) & & & & & $\begin{array}{l}-0.134 \\
(0.040)^{* * *}\end{array}$ & & & \\
\hline $\begin{array}{l}\text { External TOT } \\
\quad(\mathrm{PxPm})\end{array}$ & & & & & & $\begin{array}{l}-0.0452 \\
(0.022)^{* *}\end{array}$ & & \\
\hline $\begin{array}{l}\text { Internal TOT } \\
\text { (PxPy) }\end{array}$ & & & & & & & $\begin{array}{c}0.103 \\
(0.030)^{* *}\end{array}$ & \\
\hline $\begin{array}{l}\text { Internal TOT } \\
\text { (PmPy) }\end{array}$ & & & & & & & & $\begin{array}{c}0.145 \\
(0.030)^{* * *}\end{array}$ \\
\hline Constant & $\begin{array}{l}-1.588 \\
(0.292)\end{array}$ & $\begin{array}{l}-1.271 \\
(0.246)^{* * *}\end{array}$ & $\begin{array}{l}-1.201 \\
(0.218)^{* * *}\end{array}$ & $\begin{array}{l}-0.685 \\
(0.142)^{* * *}\end{array}$ & $\begin{array}{l}-1.240809 \\
(0.190)^{* * *}\end{array}$ & $\begin{array}{l}-.322416 \\
(0.078)^{* * *}\end{array}$ & $\begin{array}{l}0.321 \\
(0.051)^{* * *}\end{array}$ & $\begin{array}{l}-0.832 \\
(0.172)^{*+*}\end{array}$ \\
\hline No. of obs. & 1239 & 1488 & 1488 & 1454 & 1413 & 1489 & 1486 & 1484 \\
\hline No. of groups & 44 & 50 & 50 & 49 & 49 & 50 & 50 & 50 \\
\hline
\end{tabular}

Note: ${ }^{*}{ }^{* *}$ and ${ }^{* * *}=$ significance level at $10 \%, 5 \%$ and $1 \%$ respectively; and values in parentheses are standard errors.

boom are quite contrary to the long-run effects as revenues earned might have been invested into the countries' productive sectors, hence contributing positively to growth.

However, when the measure for external TOT is replaced by the internal TOT which is relative to the countries' all domestic prices, measured as $\mathrm{Px} / \mathrm{Py}$ and $\mathrm{Pm} / \mathrm{Py}$, which are less volatile, both measures are found to have a positive and significant impact on growth in both the short- and the long-run. However the magnitude of the impact on growth is relatively more pronounced in $\mathrm{Pm} / \mathrm{Py}$ as compared to $\mathrm{Px} / \mathrm{Py}$ in both the short- and long-run, signifying the increased intensity in the utilization of imported goods and their positive effects among African countries in relation to income distribution relative to the continent's exports.

\subsection{Human Capital and Demographic Influences}

The results in Table 7 show that in the long-run all the human capital variables (primary, secondary and tertiary education), have a positive and significant impact on growth, while having a positive but insignificant impact on growth in the short-run. However, when primary and tertiary education are incorporated in the model, fiscal balances exert a negative impact on growth. The negative relationship could be suggesting that government expenditures on education are being directed towards the development of skills and technological knowledge that might not be fully necessary and required for their productive application to positively contribute to growth. Also, one notices that in the long-run tertiary education is associated with relatively greater impact of gross capital formation on growth depicted by the size of the coefficient (0.52) - signifying the importance of higher education in increasing productivity of capital, while secondary education $(-0.10)$ is associated with a negative and insignificant impact of gross capital formation on growth. This could be signifying the relevance of increasing investment in both secondary and tertiary education, especially in technological knowledge and skills if Africa is to maintain its current growth performance.

However, the size of the long-run coefficients for tertiary education is relatively smaller than those of primary and secondary education, signifying a relatively weak impact of tertiary education on growth. This could be because of the low schooling returns associated with the agricultural sector (and its associated low technological change in the sector's production), upon which most of the African economies are based.

Working-age population (measured by both as working-age population growth and as a percentage of total population) is found to have a positive and highly significant impact on growth in the long-run signifying the importance of Africa's young and growing population. The same result is obtained when the working-age population is replaced by total population growth. However, in the short-run the working age population is found to have a negative and significant impact on growth. The same result is also obtained when it is replaced by the measure of demographic influences (the difference between working-age population growth and total population growth (capturing demographic influences), but positive though insignificant in the long-run, which, as argued by Sachs and Warner [23], could be attributed to the fact that in most African countries the demographic transition is at an early stage, hence the youth-dependent population is growing as rapidly or more rapidly than the total population, hence weighing on growth. 
Table 7. PMG short-run and long-run estimates of the effects of human capital and demographic factors on growth in Africa, 1980-2013.

\begin{tabular}{|c|c|c|c|c|c|c|}
\hline Variables & (1) & (2) & (3) & (4) & (5) & (6) \\
\hline \multicolumn{7}{|l|}{ Long-run estimates } \\
\hline Capital formation & $0.081(0.028)^{* * *}$ & $-0.104(0.119)$ & $0.518(0.044)^{* * *}$ & $0.502(0.058)^{* * *}$ & $0.104(0.025)^{* * *}$ & $0.172(0.033)^{* * * *}$ \\
\hline Trade & $0.085(0.063)$ & $0.656(0.158)^{* * *}$ & $0.175(0.085)^{* *}$ & $-0.060(0.084)$ & $0.086(0.056)$ & $-0.015(0.066)$ \\
\hline REER $(1997=100)$ & $-0.018(0.037)$ & $0.974(0.113)^{* * *}$ & $0.401(0.057)^{* * *}$ & $0.137(0.075)^{*}$ & $-0.068(0.039)^{*}$ & $-0.004(0.041)$ \\
\hline External debt & $-0.322(0.025)^{* * *}$ & $-0.537(0.044)^{* * *}$ & $-0.308(0.016)^{* * *}$ & $-0.280(0.025)^{* * *}$ & $-0.319(0.023)^{* * *}$ & $-0.319(0.025)^{* * *}$ \\
\hline Fiscal balance & $-0.061(0.023)^{* * *}$ & $0.182(0.036)^{* * * *}$ & $-0.025(0.020)$ & $-0.033(0.022)$ & $0.224(0.026)^{* * *}$ & $0.070(0.010)^{* * *}$ \\
\hline Primary & $0.374(0.064)^{* * *}$ & & & & $0.269(0.062)^{* * *}$ & \\
\hline Secondary & & $0.208(0.031)^{* * *}$ & & & & \\
\hline Tertiary & & & $0.1670 .02302^{* * *}$ & & & \\
\hline Total population & & & & $1.798(0.156)^{* * *}$ & & \\
\hline $\begin{array}{l}\text { Demographic } \\
\text { influences }\end{array}$ & & & & & $0.013(0.0125)$ & \\
\hline $\begin{array}{l}\text { Working-age-population } \\
\text { ratio }\end{array}$ & & & & & & $6.920(0.236)^{* * *}$ \\
\hline \multicolumn{7}{|l|}{ Short-run estimates } \\
\hline Error-correction term & $-0.092(0.029)^{* * *}$ & $-0.045(0.018)^{* * *}$ & $-0.077(0.032)^{* * *}$ & $-0.079(0.024)^{* * *}$ & $-0.083(0.033)^{* * *}$ & $-0.129(0.027)^{* * *}$ \\
\hline Capital formation & $0.074(0.024)^{* * *}$ & $0.074(0.025)^{* * *}$ & $0.056(0.027)^{* *}$ & $0.040(0.022)^{*}$ & $0.088(0.025)^{* * *}$ & $0.046(0.022)^{* *}$ \\
\hline Trade openness & $-0.095(0.036)^{* * *}$ & $-0.092(0.035)^{* * * *}$ & $-0.127(0.038)^{* * *}$ & $-0.106(0.043)^{* * *}$ & $-0.096(0.039)^{* * *}$ & $-0.092(0.036)^{* * * *}$ \\
\hline REER $(1997=100)$ & $0.411(0.064)^{* * * *}$ & $0.382(0.064)^{* * * *}$ & $0.359(0.063)^{* * * *}$ & $0.395(0.069)^{* * * *}$ & $0.448(0.065)^{* * * *}$ & $0.399(0.065)^{* * * *}$ \\
\hline External debt & $-0.290(0.041)^{* * *}$ & $-0.302(0.038)^{* * * *}$ & $-0.318(0.040)^{* * * *}$ & $-0.301(0.041)^{* * *}$ & $-0.293(0.040)^{* * *}$ & $-0.272(0.040)^{* * *}$ \\
\hline Fiscal balance & $0.038(0.033)$ & $0.033(0.042)$ & $0.035(0.031)$ & $0.028(0.028)$ & $0.032(0.038)$ & $0.027(0.025)$ \\
\hline Primary & $0.002(0.096)$ & & & & $0.060(0.113)$ & \\
\hline Secondary & & $0.053(0.041)$ & & & & \\
\hline Tertiary & & & $0.006(0.020)$ & & & \\
\hline Total population & & & & $-0.993(0.652)$ & & \\
\hline $\begin{array}{l}\text { Demographic } \\
\text { influences }\end{array}$ & & & & & $-0.036(0.021)^{*}$ & \\
\hline $\begin{array}{l}\text { Working-age-population } \\
\text { ratio }\end{array}$ & & & & & & $-6.075(2.369)^{* * *}$ \\
\hline Constant & $0.498(0.151)^{* * * *}$ & $0.062(0.019)^{* * * *}$ & $0.272(0.112)^{* * * *}$ & $-1.783(0.508)^{* * *}$ & $0.514(0.204)^{* * *}$ & $-2.588(0.551)^{* * *}$ \\
\hline No. of obs. & 1205 & 1239 & 1239 & 1239 & 1289 & 1239 \\
\hline No. of groups & 43 & 44 & 44 & 44 & 50 & 44 \\
\hline
\end{tabular}

Note: ${ }^{* * *}$ and ${ }^{* * *}=$ significance level at $10 \%, 5 \%$ and $1 \%$ respectively; and values in parentheses are standard errors.

It is also observed from the results that the negative impact of tertiary education on growth in Africa is associated with a reduction in the magnitude of the long-term impact of working-age population depicted by the reduced size of the coefficient in relation to the size in the other models. ${ }^{6}$ This might be suggesting the lack of required skills among the youth that could significantly contribute to growth or a very small percentage of the age group has access to the tertiary education required to enhance growth. Calling for the need to equip this age group with the necessary skills by enhancing access to tertiary education among African countries. This is also

${ }^{6}$ Note that the results have not been incorporated in the table but are available upon request from the author. 
supported by the results of the variable-difference between the working age population and the population growth rate (demog) — which is found to be negative and significant in the short-run but positive though insignificant in the long-run.

\section{Conclusions and Policy Recommendations}

This study has tried to empirically examine the impact factors believed to be driving Africa's recent growth. The study employs the recent analytical methodology to assess the long-term impact of the identified factors using the PMG estimation method. The results support the narrative that Africa's recent growth has mainly been driven by improved macroeconomic management which to some extent support the effects of the fiscal consolidation and monetary policy measures being undertaken by most African countries, the demographic influences as a result of increasing working-age population, increased trade, especially as a result of relatively high commodity prices experienced over the period.

However, despite Africa's recent robust growth performance, results show that external debt continues to weigh significantly on the countries' growth. Therefore, for African countries to maintain the prevailing growth momentum, there is need to reduce appetite for foreign aid and reduce the debt burden which continues to derail the countries' growth. This calls upon African countries to domestically explore innovative sources of financing, leveraged from new partnerships, and innovative instruments for domestic resource mobilization such as private equity. This can be done through strengthening the role of bond markets, pension funds and sovereign wealth funds to boost investments.

Despite experiencing relatively low inflation rates and stable exchange rates in some countries, the findings of this study show that these variables still seem to exert negative pressures on the countries' economies. Emphasis on macroeconomic policy should therefore, not only focus on stabilization and achieving low inflation, but also on supporting strong, sustained and inclusive growth.

The study finds also that, despite a significant increase FDI into Africa, leading to significant growth impacts in some countries, it has a detrimental effect on growth in Africa. This can be because a greater proportion of FDI is directed towards sectors with minimal potential of job creation, such as those in the extractive sector. The results suggest also that this negative impact can be associated with the lack of capacity to fully utilize the benefits that come with FDI, especially in relation to human capital development. Hence the need to develop the necessary human capital and technological capacity, especially through secondary and tertiary education, to fully reap the development benefits from FDI.

\section{References}

[1] Brixiova, Z. and Ndakumana, L. (2010) Supporting Africa’s Post-Crisis Growth: The Role of Macroeconomic Policies. Working Paper No. 117, African Development Bank. www.afdb.org/

[2] McKinsey Global Institute (2010) What's Driving Africa's Growth. www.mackinsey.com/mgi

[3] Sy, A. (2014) Is Africa at a Historical Crossroads to Convergence? Global Economy and Development, Africa Growth Initiative, Brookings Institution.

[4] ECA (United Nations Economic Commission for Africa) and AUC (African Union Commission), 2014. Economic Report on Africa: Dynamic Industrial Policy. ECA, Addis Ababa.

[5] McKinsey Global Institute (2010) Lions on the Move: The Progress and Potential of African Economies. www.mackinsey.com/mgi/

[6] ECA (United Nations Economic Commission for Africa) (2015) Economic Report on Africa: Industrializing through Trade. ECA, Addis Ababa.

[7] Drummond, P., Thakoor, V. and Yu, S. (2014) Africa Rising: Harnessing the Demographic Dividend. IMF Working Paper No.WP/14/143, African Department, IMF, Washington DC.

[8] World Bank (2015) World Development Indicators (WDI) and African Development Indicators (ADI) Databases.

[9] Economist Intelligence Unit (EIU) (2015) EIU Database. www.eiu.org

[10] Arkhangelskaya, A. (2015) What Does BRICS Cooperation Mean for African Trade and Sustainable Development? Bridges Africa, 4.

[11] Ernest and Young (2014) EY’s Attractiveness Survey: Africa 2014 Executive Growth. www.ey.com/attractiveness

[12] Barro Robert, J. (1990) Government Spending in a Simple Model of Endogenous Growth. Journal of Political Econo- 
my, 2, 103-125. http://dx.doi.org/10.1086/261726

[13] Ramey, G. and Ramey, V. (1995) Cross-Country Evidence on the Link between Volatility and Growth. American Economic Review, 85, 1138-1151.

[14] Coulier, P. and Goderis, B. (2012) Commodity Prices and Growth: An Empirial Investigation. European Economic Review, 56, 1243-1260. http://dx.doi.org/10.1016/j.euroecorev.2012.04.002

[15] Islam, N. (1995) Growth Empirics: A Panel Data Approach. The Quarterly Journal of Economics, 110, 1127-1170. http://dx.doi.org/10.2307/2946651

[16] Simoes Marta, C.N. (2011) Education Composition and Growth: A Pooled Mean Group Analysis of OECD Countries. Panoeconomicus, 4, 455-471. http://dx.doi.org/10.2298/PAN1104454S

[17] Pesaran, M.H., Shin, Y. and Smith, R. (1999) Pooled Mean Group Estimation of Dynamic Heterogenous Panels. Journal of the American Statistical Association, 94, 621-634. http://dx.doi.org/10.1080/01621459.1999.10474156

[18] Pesaran, M.H. and Smith, R. (1995) Estimating Long-Run Relationships from Dynamic Heterogeneous Panels. Journal of Econometrics, 68, 79-113. http://dx.doi.org/10.1016/0304-4076(94)01644-F

[19] Freeman, D.G. (2000) Alternative Panel Estimates of Alcohol Demand, Taxation, and the Business Cycle. Southern Economic Journal, 67, 325-344. http://dx.doi.org/10.2307/1061473

[20] Blackburne, E.F. and Frank, M.W. (2007) Estimation of Nonstationary Heterogeneous Panels. The Stata Journal, 7, 197-208.

[21] Pirotte, M. (1999) Convergence of the Static Estimation towards the Long-Run Effects of Dynamic Panel Data Models. Economic Letters, 63, 151-158. http://dx.doi.org/10.1016/S0165-1765(99)00023-3

[22] Pesaran, M.H., Shin, Y. and Smith, R. (1997) Pooled Estimation of Long-Run Relationships in Dynamic Heterogenous Panels. ESE Discussion Papers No. 16, Edinburgh School of Economics, University of Edinburgh, Edinburgh.

[23] Sachs, J.D. and Andrew, W. (1997) Sources of Growth in African Economies. Journal of African Economies, 6, 335376. http://dx.doi.org/10.1093/oxfordjournals.jae.a020932

[24] Bangake, C. and Jude, E. (2012) Pooled Mean Group Estimation on International Capital Mobility in African Countries. Research Economics, 66, 7-17. http://dx.doi.org/10.1016/j.rie.2011.06.001

[25] Pedroni, P. (1999) Critical Values of Cointegration Tests in Heterogenous Panels with Multiple Regressors. Oxford Bulletin of Economics and Statistics, 61, 653-670. http://dx.doi.org/10.1111/1468-0084.61.s1.14

[26] Baltagi, B.H., Griffin, J.M. and Xiong, W. (2000) To Pool or Not to Pool: Homogenous versus Heterogenous Estimators Applied to Cigarette Demand. Review of Economics and Statistics, 82, 117-126. http://dx.doi.org/10.1162/003465300558551

[27] Africa Progress Panel. (2013) Africa Progress Report 2013: Equity in Extractives. www.africaprogresspanel.org

[28] ECA (United Nations Economic Commission for Africa) and AUC (African Union Commission) (2013) Economic Report on Africa 2013: Making the Most of Africa's Commodities: Industrializing for Growth, Jobs and Economic Transformation. ECA, Addis Ababa.

\section{Submit or recommend next manuscript to SCIRP and we will provide best service for you:}

Accepting pre-submission inquiries through Email, Facebook, LinkedIn, Twitter, etc.

A wide selection of journals (inclusive of 9 subjects, more than 200 journals)

Providing 24-hour high-quality service

User-friendly online submission system

Fair and swift peer-review system

Efficient typesetting and proofreading procedure

Display of the result of downloads and visits, as well as the number of cited articles

Maximum dissemination of your research work

Submit your manuscript at: http://papersubmission.scirp.org/ 